Article

\title{
A Case Study: Mada Masr-A Progressive Voice in Egypt and Beyond
}

\author{
Nadia Leihs \\ Independent Researcher, Germany; E-Mail: leihs@gmx.de
}

Submitted: 8 May 2021 | Accepted: 5 October 2021 | Published: 17 December 2021

\begin{abstract}
This article questions the role of the media in times of political transformation. In doing so, it draws on theories on the interconnectedness of the different fields of society to explain the sets of roles that media outlets and journalists adopt during phases of transition. Before 2011, the Egyptian media mostly acted as collaborators of the ruling regime and rarely as an agent of change. Journalists took over the latter role more often following the advent of privately-owned media outlets, thus helping to pave the way for the events of the so-called Arab Spring. This case study focuses on the development of the online news portal Mada Masr and therefore traces the development of two newsrooms. Starting as the English edition of a privately-owned Arabic newspaper in 2009 and changing its status to an independent news outlet in 2013, Mada Masr is one of the few voices which still openly criticise the Egyptian government. Founded in a time of political turmoil and struggling against an increasingly authoritarian environment, the outlet implements innovative ways of producing content, securing funding, and reaching out to its readers. A group of young Egyptian and international journalists make use of new spaces for expression that have opened through the global changes in communication infrastructure while struggling with frequent attacks by representatives of the ruling regime. As such, Mada Masr is a role model for small and regime-critical media outlets.
\end{abstract}

\section{Keywords}

alternative media; Arab Spring; authoritarianism; Egyptian media; Mada Masr; media systems; media transitions; online journalism

\section{Issue}

This article is part of the issue "Ten Years after the Arab Uprisings: Beyond Media and Liberation," edited by Hanan Badr (Gulf University for Science and Technology, Kuwait) and Lena-Maria Möller (Max Planck Institute for Comparative and International Private Law, Germany).

(C) 2021 by the author; licensee Cogitatio (Lisbon, Portugal). This article is licensed under a Creative Commons Attribution 4.0 International License (CC BY).

\section{Introduction}

The development of the Egyptian media scene reflects the political power struggles in Egypt since long before the so-called Arab Spring. While the legal system, ownership structures, and direct interference by representatives of the ruling regime work against the principles of media freedom, single journalists and media outlets like Mada Masr act as agents of change in a repressive environment. The journalists working for the bi-lingual news portal are constantly negotiating the limits of what can be published and have carved out a niche of their own after being forced to leave the mainstream media infrastructure in 2013. In contrast to Egypt's highly uniform mainstream media, Mada Masr gives voice to the power- less and covers underreported topics. In the meantime, experiments to increase its outreach involve collaboration with other media outlets as well as non-journalistic partners across national borders or a membership program. In moving from being the English-language online section of an Arabic newspaper to an autonomous organisation the news outlet underwent shifts in its structure, rearranging its hierarchy and routines.

Mada Masr presents itself as an actor instead of a mere observer and narrator, a role that in contrast to many of their Western colleagues, Egyptian journalists have since long claimed for themselves. In the case of Mada Masr, its staff had been part of the progressive movements that enabled the events of 2011 and has since continued to fill the gaps left by the lack of an 
assertive political opposition. Conducting an analysis of its agency aims to outline what tools and strategies the news outlet uses to defy power structures, resist and cope with threats by security forces, and survive despite the hostile conditions created by the oppressive political regime.

This theory-informed case study builds on a combination of different materials, including primary sources such as newsroom observation, interviews conducted with members of the editorial team, and monitoring of the content of the analysed publications as well as secondary sources such as research or journalistic reports. Fieldwork was conducted in Cairo during several stays between March 2011 and December 2013. As part of a larger study, six semi-structured interviews with members of the newsrooms Al Masry Al Youm English Edition (later: Egypt Independent) and Mada Masr, and informal interviews with a former copy editor were conducted in English by the author. The interviews took place in different newsrooms and, except for the informal interviews, were audio-taped and transcribed. The interviewees occupied different positions in the newsrooms and were all in their twenties at the time of the interview. In order to minimise the risk of bodily or other harm due to the heightened political repression in Egypt, the full names of the interviewees will not be disclosed. Material from later periods was collected through publications of the news outlet itself, journalistic reports, and academic literature.

In its first part, this article discusses the role of the media in societal transformation processes, taking into account the interdependency of the different social systems. This is followed by an outline of the development of the outlet during a decade of significant change in the Egyptian media, and a closer look at its journalistic self-image and production structures and routines.

\section{Media and Transformation}

The transformation of a media system takes place in parallel to a panoply of transformations in other parts of society. While all of a society's parts, be it the media, the economic, or the political system, share the same framework based on common historical roots, they mutually shape their development and their relationships with each other (Hallin \& Mancini, 2004, p. 46).

Social norms and values result from socially negotiated processes and are therefore changeable and sometimes even contradictory (Shoemaker \& Vos, 2009, p. 106). How the media reflects change in its environment is highly dependent on its role in society and how social and other transformations are accepted and supported by the social system. Due to the dynamic relationships between all parts of society, the media system not only is shaped by but also affects its surrounding environment (Hafez, 2014, p. 244; Shoemaker \& Reese, 2014, pp. 69-72). Change must be understood as sequences of subtle shifts during which actors are con- strained by their surroundings while concurrently transforming them (Roudakova, 2011, p. 252). The impact of the media on social or political transformation processes is therefore not unambiguous.

While some parts of the media act as pioneers and press for further change, often the media is accused of maintaining "a system of control and reproduction of the dominant ideology" (Shoemaker \& Reese, 2014, p. 65) and as such is seen as an obstacle to social or political change. However, when the struggle over the preservation of hegemonic structures and the pursuit of social change reaches the public arena, the media will reflect the conflict between order-maintaining and ordereroding forces, and especially independent media can become "inherent sources of instability" and as such, drive change (Roudakova, 2011, p. 250). Research indicates that regardless of the political or social context, media can act positively as agents of change during times of transformation by enhancing citizens' understanding of democratic values and processes (Voltmer, 2013, pp. 110-114).

Change in a media system alone cannot cause transformation in other fields such as the economic or the political system but must be accompanied by enabling factors in its environment (Hafez, 2014, pp. 235-236). Transformations in media systems have often been predated by politically supported decentralisation and privatisation, which opened the media market to more competition and, as a result, to the publication of a wider variety of voices and opinions.

In Egypt, privately-owned newspapers such as Al Masry Al Youm (The Egyptian Today) were not the only new players in the media scene that since the last decade of the 20th century competed successfully for impact, advertising money, and readership, and had to be taken seriously in the newsrooms of state-owned media houses. The pressure to include previously taboo topics and dissident perspectives grew with the tremendous success of pan-Arab media such as Al Jazeera (The Island) and new communication channels such as blogs and social media (Elmasry, 2009, pp. 113-115; Fandy, 2000, p. 389). The scope of political protests in early 2011 must be explained by many factors, not the least by the opening of the media scene (Khoury, 2012, p. 80; Rinke \& Röder, 2011, pp. 1276-1278).

On the other hand, the unaccustomedly outspoken media outlets often were owned by members of the political and economic elite. Ownership structures ensured that the media only acted as a safety valve and did not cross the red lines of those in power, and as such, were an obstacle to efforts for a real transformation of the media (Richter, 2011, p. 81). Additionally, journalists had to cope with restrictions and intimidation from authorities, difficulties in accessing information, and a limiting mindset brought from senior editors who had learned their profession in the state-owned media (UNESCO, 2013). Therefore, editorial censorship and self-censorship remained a part of journalists' work 
in Egypt, although it was often disguised as responsible reporting (El Issawi, 2020, p. 638; El Issawi \& Cammaerts, 2016, p. 556; Sakr, 2013, pp. 160-161).

One difficulty for transforming media systems lies in the heritage of ingrained organisational structures and professional practices and values; they shape its inner workings and the power relations that connect it to other institutions and frame the outcome of all transformative efforts (Downing, 1996, p. 203). Only if problematic aspects of its heritage, be they its structures, values, or practices, are addressed and tackled, can sustainable change take place. This might involve debate over the degree of press freedom, the extent of government influence, or the professionalisation of journalists. Conflicts between journalists and political actors, for example, can lead to the publication of biased reports favourable to ideological friends and thus ultimately form an obstacle to fruitful discourse about the future of society (El Issawi \& Cammaerts, 2016, p. 552).

Since 2013, and after the ousting of President Mohammed Morsi of the Muslim Brotherhood's party Hurriya wa Adala (Freedom and Justice), the Egyptian media has become less free than ever (Badr, 2017, p. 138), even though a specious plural media scene with media outlets run by state authorities, parties, and private investors was sustained. The regime, being ruled once again by a military man, cracked down on political opponents and the media alike. Violence, imprisonment, and show trials were used to enforce submission from outspoken national and international journalists (Richter, 2015, p. 131). In addition, the regime geared up legal provisions and its technical ability to monitor digital communication channels (Hamoud, 2019, p. 129). In June 2020, at least 549 national and international media portals were blocked and placed out of reach of Egyptian citizens (Association for Freedom of Thought and Expression, n.d.).

Borrowing from political science, Jones (2002) developed a theoretical model for the transformation of media systems consisting of four ideal stages of transformation shifting from a hard form of authoritarianism to a democratic press system. As Jones (2002) demonstrates, part of these developments is the multiplication of forces influencing the media organisations as well as the individual journalist and the journalistic content in general. Transformation is not a linear process but is very likely to show parallel, sometimes even contradictory trends, with the ever-present risk of regression (Jones, 2002, pp. 66-72, 488-496).

\section{Mada Masr: A Case Study}

\subsection{A Short History of Two Egyptian Newsrooms}

Mada Masr was founded in 2013 by staff from the English edition of the Egyptian newspaper Al Masry Al Youm. The term Mada "is the Arabic word for range, scope or span, but it is also the spot where a stone is placed on a ring, a symbol of taking a position" ("And we're back," 2013), the word Masr translates to Egypt.

Founded in early 2009, the English edition published translated pieces from its parent paper as well as its own reporting online. Translations often were amended with contextual information for an audience that was not overly familiar with Egyptian politics, geography, or history (personal interviews). Led by the journalist Fatemah Farag, approximately ten experienced media professionals ran the newsroom. Some of its original stories on human rights issues were eventually translated and featured on the pages of Al Masry Al Youm (Abdallah, 2014; Sandels, 2009).

The team enjoyed a wider margin of acceptable topics than their colleagues at the Arabic language daily, but conflicts about administrative issues and journalistic content between senior editors of both outlets occurred frequently. This led to the walk-out of three leading editors in May 2010, the changing of its name to Egypt Independent in November 2011, and the halting of news production and the resignation of most of its staff in January 2013.

From early on, it was clear to Farag and her team that "we have our red lines too" (Sandels, 2009). Although the staff of the English edition refused to censor themselves, they carefully weighed the risks of reporting. By reading through the coverage of other Egyptian media, they assessed how and around which topics the red lines of reporting fluctuated. Its professional standards were informed both by journalistic practices and routines stemming from its authoritarian surroundings and Western journalistic cultures. Editors and contributors were young, educated, liberal-minded, and well connected to the political opposition groups that had been involved in the run-up to the massive protests of January and February 2011.

In a time of political turmoil, having witnessed the ousting of long-time president Hosni Mubarak in 2011, the first free elections in Egyptian history and the media wars that followed in 2012, and with the deposition of President Morsi looming, the dismissed staff decided to found a new media institution. The website went online one day before the massive demonstrations of June 30th, 2013, which led to the military-backed ousting of Morsi. There was no coincidence in coming back on that particular day, but rather a conscious decision: "We wanted to re-appropriate our journalism on this heated day because it is through the prism of this craft that we engage with politics and activism" ("And we're back," 2013).

Mada Masr reported extensively about the demonstrations and sit-ins of the following weeks as well as the violent break-up of the pro-Morsi sit-ins in August 2013, delivering vivid descriptions and glimpses of the mindsets of protesters from both political camps as well of those living in the surrounding areas. Their reporting referenced past political developments as part of the causes for the current upheaval and depicted the 
heterogeneous reasoning on both sides of the political conflict. From early on, Mada Masr's authors drew its audience's awareness to the dwindling space for alternative voices outside of the mainstream, describing the spiralling polarisation and predicting further violence. To create the new media institution, the editors occupied positions traditionally not connected to the professional life of journalists and experimented with new journalistic formats and forms of funding, deepening their connections to like-minded local and international communities. It was, however, mainly the technical opportunities of digitalisation and a strong interest of philanthropists in media development that enabled the outlet to survive and thrive.

Since May 2017, Mada Masr has had to circumvent a cyber-attack that has kept its Egyptian audience from accessing the website directly (Association for Freedom of Thought and Expression, n.d.; "Becoming 'legal,", 2018). Several Egyptian authorities denied responsibility, and no official explanation has yet been given as to why the page was blocked ("Neither victory nor defeat," 2018). Back in 2017, a "high-level security source" confirmed to the media that the block was aimed at pages that published "contents that support terrorism and extremism and deliberately spread lies" (Hamama, 2017). In response to the blocking of their website, the news outlet had to develop new ways of reaching out to their Egyptian audience-among them the set-up of mirror pages, frequent change of their addresses to avoid further blocking, and the increased use of its social media channels. The constant attacks also led to a different perception of technology: "The internet is going from being a home to being the new state....We are fighting a legal and technological battle using the same tools that are made to oppress us" (Attalah, 2017). According to a newsletter to its members, the website came under "major DDoS attacks since December [2020]," which forced the outlet to upgrade its servers (Mada Masr, 2021).

Following legal reforms in summer 2018, Mada Masr applied for a publishing licence with the Supreme Media Regulatory Council in October ("Becoming 'legal,'” 2018). As of today, no decision has been made, while Egyptian authorities have given contradictory statements on the legality of the newsroom's operation (Fahmy, 2019).

Events such as the widespread protests in early 2011 and mid-2013 marked the shift from a system of soft authoritarianism through a phase of transition and the backsliding to a form of hard authoritarianism in the present (Jones, 2002, p. 64). During these different phases of political transition, journalism in Egypt was faced with varying challenges and opportunities. Badr (2020, p. 226) observes that throughout the Egyptian media scene, the "desire for autonomy exists in various forms." But while most Egyptian newsrooms consist of subgroups divided over the best approach to achieve independence from external forces, the team of Mada Masr presents itself as a rather homogenous "single community" (Badr, 2020, p. 224). Despite staff changes, the alternative media outlet kept following a journalistic approach "outside the realm of mainstream media" (Badran \& Smets, 2018, p. 4321). It covered sensitive issues such as worker's protests-thus pushing for change-from its foundation in 2009, providing in-depth analysis and reporting on the different political players during the transition phase from 2011 to 2013. Furthermore, they adhered even more strictly to professional norms such as balanced reporting and fact-checking as a part of their strategy to challenge the tightening grip of the increasingly hostile political regime following the ascent of current president Abdel-Fattah el-Sisi (Badr, 2020, p. 223). Despite being in a constant legal and financial limbo and facing further attacks such as a raid of the newsroom in 2019, the arrest of several staff members in 2019 and 2020, travel bans, expulsions, and the self-imposed exile of several staff members, Mada Masr today is internationally acknowledged as a beacon for freedom of speech in Egypt. In 2019, the news outlet was named Free Media Pioneer by the International Press Institute (International Press Institute, 2019). Time magazine chose recurring chief editor Lina Attalah as a Next Generation Leader in 2017 (Time, n.d.) and considered her among the 100 Most Influential People of 2020 (Ressa, 2020).

\subsection{Journalistic Roles in the Newsroom of Mada Masr and Beyond}

Extensive knowledge of the English language had been key to becoming a member of the editorial team before 2013. Consequently, the Egyptian staff of the English edition of Al Masry Al Youm had been recruited from other Egyptian English-language outlets, international media, and graduates from English-language education institutions, in addition to foreign journalists living and working in Egypt (Chang, 2015). This prerequisite naturally restricted recruitment and simultaneously shaped the newsroom as a space occupied by liberal-minded journalists, who were invested in (human rights) activism (Dean, 2017, p. 13; see also Chammah, 2011). While embracing professional standards of Western journalism such as factuality and balance, operating in an authoritarian environment transcended the staff's perception of journalistic objectivity with staff not viewing themselves as purely neutral observers who must simply deliver both sides of a story. Talking about her first day in journalism in 2002, a senior reporter recalled: "And it was my first time to get exposed to violence that comes along demonstrations in Egypt....It was quite an eye opener, like I tapped into this other world of activism and politics" (personal communication).

The editorial staff of both outlets had relationships with and partially became part of the liberal Egyptian opposition (Attalah, 2017; Attalah \& Mossalam, 2014), which consisted of formal organisations such as unions or political parties as well as informal interest groups 
(Wackenhut, 2019). While being guided by professional standards mostly assigned to monitorial and facilitative roles, objective and neutral reporting, and the enabling of political participation (El Issawi \& Cammaerts, 2016, p. 551), having to cope with increasing authoritarianism inevitably led staff to take an adversarial position toward the ruling powers. When military-backed protests forced then-president Morsi out of office in 2013, the staff tried to do "the basics of journalism: objective reporting, both sides of the story," but became a "de facto opposition organisation" due to the lack of voices opposing the violent crackdown against members and supporters of the Muslim Brotherhood (Dean, 2017, p. 11).

Consequently, founding a media outlet as "a political project, with a mission and a responsibility" was born out of individual interests as well as of political circumstances: "It was perhaps a return to the position we had before the revolution, the margin, as the place of the unorthodox, the unconventional and the critical" (Attalah, 2017). In Western, namely US-American journalism, adversarial journalism has clearly increased from 1982 to 2013, while the interpretative and the disseminator function are still considered dominant (Weaver et al., 2018, p. 17). In 2018, Mada Masr stated: "Our goal has always been to produce adversarial journalism" ("Becoming 'legal,"' 2018). The staff is aware of its double-role as journalists and politically involved individuals and, through its writings, makes the struggle between personal investment and professional conduct transparent:

Part of the job has become to fight off that nagging voice in the back of my head: does it even matter?....Seeing injustice rise to unprecedented heights and mainstream media become a synchronised stateworshipping orchestra, the need for journalists who attempt to report the truth, broken and demoralised as we may be, is more evident than ever. While the joy of journalism may have momentarily escaped me, the sense of purpose is stronger than ever. (Afifi, 2014).

Journalism became vital, a means of survival, a life purpose. "I think if Mada didn't exist, I would be very reluctant to stay in this country," Attalah said in an interview (Chang, 2015). A few years later, she described journalism as "a highly political act of contention" in the face of repression and journalists' role as "political agents" (Attalah, 2019, p. 2).

Rejecting the role of a neutral, detached observer is not an exceptional perception of professional values and standards among Egyptian journalists who, in discussion with scholars, have stated that they follow a "professional bias" (El Issawi, 2020, p. 640), "managing my bias" (Harb, 2018, p. 12), or otherwise taking a political stand instead of striving for objectivity (personal interviews in different Egyptian newsrooms). Politicised journalism isn't new to the media in Egypt as it for long had been in service of the ruling powers and, as such, had distributed government propaganda and often adopted a collaborative role (El Issawi, 2020, p. 629; El Issawi \& Cammaerts, 2016, p. 553; Elmasry, 2009, p. 8). Political lines became blurred between 2011 and 2013, with the Egyptian media "torn between high-flying hopes and persisting constraints" amidst the power struggles between the old guard, Islamist currents, and liberal forces (Vladisavljevic \& Voltmer, 2017, p. 20). During the transitional phase of 2011 to 2013, many journalists practised an interventionist role (El Issawi, 2020, p. 632), embracing a "hybrid identity of the journalist-activist" (El Issawi, 2020, p. 629) and adapting the "personalized and emotional style of bloggers" (El Issawi, 2020, p. 639). Early on, during the short rule of the Muslim Brotherhood's Mohammed Morsi, the movement and its party were framed by many mainstream media outlets as dangerous power grabbers unfit to rule the country. By taking over the "activist or radical role....Egyptian journalists also fuelled the political fragmentation of Egyptian society" (El Issawi \& Cammaerts, 2016, p. 563).

Even though it is clear that the Egyptian media wars of 2012 and 2013 were not solely the cause of the disruption of the political transformation (Badr, 2017, p. 157), the majority of the Egyptian media was not fit to facilitate a reasoned debate about the course of the political transformation. In the summer of 2013, protests by Morsi supporters were unanimously demonised as illegitimate by the Egyptian media; its violent dispersal was greeted by most journalists and commentators as an inevitable strike against terrorists (El Issawi \& Cammaerts, 2016, pp. 554-561). Many media outlets allied with the Muslim Brotherhood were closed immediately, while most Egyptian newsrooms fell into line with the official "War against Terror" (Richter, 2015, p. 137). Blacklists of unwanted voices and topics became a common routine again (Hill, 2013). In the aftermath of the events of summer 2013, "journalists adapted again to editorial 'orders' in the name of 'exceptional' conditions" and returned to "their identity as guard of the regime" (El Issawi, 2020, p. 639).

Despite most of the Egyptian mainstream media falling in line, studies indicate a "hybridity of roles and professional norms" (Harb, 2018, p. 14) and a "nuanced agency" among Egyptian journalists (Badr, 2020, p. 226). Dissident journalists turned to publishing reports through their personal accounts on social media and in alternative media such as Mada Masr to counter the censorship by editors in the newsrooms of the stategoverned and privately-owned media (Harb, 2019, p. 6). Journalists in mainstream media outlets often form a set of "diverse and shattered subgroups" (Badr, 2020, p. 224) and are able to "swiftly move from one political camp to another to secure the continuity of their media presence" amidst the changing dynamics of alliances between media owners and political actors (El Issawi, 2020, p. 634).

Although the alternative media scene itself certainly is not homogenous (Badran \& Smets, 2018, p. 4243), 
the team of Mada Masr possessed a "sense of collective and of being "part of a minority community'" (Sakr, 2016, p. 12; see also Badr, 2020, p. 224) and of being connected through mutual political convictions and professional values. Although accustomed to a higher degree of editorial freedom, the editors of Mada Masr did exercise caution. One journalist reported not having identified herself as a member of Mada Masr for some time when talking to sources out of fear of putting the whole media outlet at risk (Chang, 2015). During editorial meetings, discussions regularly evolved around the balancing act of reporting all issues the journalists wanted to address without endangering the future of the news portal (Schröder, 2015, p. 28). Furthermore, being confronted with an ever-rising threat of harassment, and worse, by state authorities, the team applied "survival strategies" such as "rigorous fact-checking... and even omitting carefully researches pieces" (Badr, 2020, p. 223) to protect the outlet from being shut down.

\subsection{Producing Mada Masr}

Breaking away from its parent paper did open up new opportunities to produce different content, reach out to a wider readership, and include new voices. Although the portal started its publication with English-only articles, publishing in Arabic was "at the core" of the new media operation from the beginning (personal communication). In an interview, Lina Attalah described the opportunity to publish in Arabic as "one of the liberating thoughts" after having been kicked out by Al Masry Al Youm because "[w]e always felt that what we were writing was not necessarily directed to foreigners" (Hagmann, 2013). Although pieces from the English edition occasionally had been translated and printed in the Arabic parent paper, the hierarchical and administrative structure did not allow for autonomous decisions by the English editors on which pieces to publish in Arabic.

Becoming a bi-lingual online news portal also allowed the inclusion of authors who could not be published before as their knowledge of the English language was too limited to write complex news articles and analyses. Today, Mada Masr publishes more content in Arabic than in English, such as a daily bulletin with local and international news. While parts of their reporting are translated to English, pieces directed mainly to the Egyptian audience, such as current reporting on accidents, cultural events, or service pieces, are published in Arabic only. Often, the English translations are published a few days after the Arabic article; translations range from longer analyses, opinion pieces, as well as soft topics on well-being and cooking. Attalah explained in an article discussing the relevance of Mada Masr, the Jordanian 7iber, and al-Jumhuriya (an online outlet run by Syrian exiles, on a pan-Arab level) that:

Translating some content into English, and, to a lesser extent... generating original content in English, [is] all with the interest of being part of the global conversation. Throughout, we have been exposed to the woes of translation, and have grappled with how often part of the original essence is lost. (Attalah, 2019, p. 12)

Despite the expenditure, Mada Masr continues to publish in both languages as "there is more attention paid towards the English-speaking media, specifically the international media, just because of how they can embarrass our regime" (Hussein, 2019).

Mada Masr continuously addresses contentious issues which are omitted by the majority of the Egyptian media, such as the ongoing suppression of political dissent. One outstanding example of its efforts to provide alternative perspectives certainly is the reporting of the ongoing clashes between terrorist groups and the Egyptian army in North Sinai and their toll on its civil population. Although journalists' access to the region is restricted, Mada Masr has frequently reported since 2017 and introduced a weekly bulletin in April 2019.

In 2015, Mada Masr published in-depth reports on several documents revealed by WikiLeaks on the influence of Saudi Arabia on Egyptian politics (Abdelhadi, 2015). In 2019, it shed light on the reporting of the death of former Egyptian president Mohamed Morsi in a courtroom ("42 words on page 3," 2019). Producing a daily review of the Egyptian media had been introduced back when the news portal was still a part of Al Masry Al Youm, and-under the title of Daily Digest-this has become one means of securing the outlet's budget. Other rather sensitive issues range from labour conflicts to forced disappearances and the circumstances of (political) prisoners in Egypt, or the taboo subject of sexuality, including the situation of Egypt's LGBT community or victims of sexual violence.

Additional formats are constantly developed: Since May 2019, an Arabic-language daily news bulletin has covered a broad spectrum of national and international news with only a small portion of its contents translated to English. In August 2019, a bi-lingual weekly bulletin with lifestyle content such as book, film, or music recommendations followed suit.

Being originally a news outlet addressed at foreigners and readers in the diaspora, the editorial team never focused on an instant reporting of events but rather aimed to provide in-depth journalism with analysis and background information. This still rings true as the journalists employ "data-powered investigations, ethnographic reportage, and fact-based analysis... while staying relevant, and not falling into a sort of lazy elitism that this form of production can risk" (Attalah, 2019, p. 7).

Compensating for the effects of being blocked in Egypt, Mada Masr intensified its use of social media and registers constantly rising numbers of followers (see Table 1). The social media team posts and tweets headlines and summaries of currently published pieces along with the current address of the mirror page, which allows readers from Egypt to access the webpage in Arabic and 
Table 1. Followers and subscribers of Mada Masr on Facebook, Twitter, and YouTube.

\begin{tabular}{lrrr}
\hline Social Media Channel & $2018^{1}$ & $2019^{2}$ & $2021^{3}$ \\
\hline Facebook & 209,337 & 215,000 & 303,301 \\
Twitter & 111,939 & 114,000 & 192,224 \\
YouTube & 21,568 & 22,260 & 62,000 \\
\hline
\end{tabular}

Sources: ${ }^{1}$ Media Ownership Monitor Egypt (2018), ${ }^{2}$ "How necessity drives" (2019), ${ }^{3}$ data from Mada Masr social media channels compiled in 2021 by the author.

English. In addition, social media is employed for solidarity campaigns and advertisements for additional services or special events. Among the videos posted on its YouTube channel, the satirical series Akh Kebir (Big Brother) attracted a wide audience nationally and regionally before author and caricaturist Andeel stopped it in August 2019 due to security concerns ("Wrestling in Egypt," 2018).

Since 2013, Mada Masr has run a Soundcloud account, promoting local artists, sharing editors' favourite music, and posting interviews and audio features. Since April 2021, members can access a special Soundcloud channel with recordings of discussion rounds on current topics from parliamentary sessions to cybersecurity.

The team established and developed different event formats to build a lasting relationship with their audience that extends from the political to the private and the popular. Starting with a party to generate enough money to save Egypt Independent from closing in 2012 (Dean, 2017, p. 9), members of the newsroom took part in gatherings such as marketplaces, concerts, film screenings, or panel discussions. In doing so, Mada Masr attempted to strengthen the bond with its audience as well as with local musicians, artists, and entrepreneurs. Many of these events were developed in collaboration with local organisations such as Megawra, which links questions of housing with those of cultural heritage and social responsibility.

Understanding its audience as "a means to build power" (Attalah, 2017), the editors address Egyptian readers as well as the "broader, transnational community that empowers us" ("Wrestling in Egypt," 2018) and has attracted "more mainstream audiences over the years" (Hussein, 2019). Although audience research in Egypt is scarce, the Mada Masr team has stated in interviews that while the outlet's Egyptian audience tends to read both the English and the Arabic version of the portal, its Arabic audience is more diverse than its English readership (Sakr, 2016, pp. 15-16). While it is beyond the scope of this article to research the impact of the outlet's content on its audiences' belief systems, it can be stated that Mada Masr acts as an "alternative forum" (Harb, 2019, p. 4) delivering "counter hegemonic discourses and identities' " (Badran \& Smets, 2018, p. 4321). In addition, some of Mada's reporting has been further circulated by other Egyptian media (Sakr, 2016, p. 15). Therefore, the outlet contributes to a diversification of perspectives in an increasingly homogenous media market, thus helping to "foster political engagement by increasing citizens' knowledge of current issues" (El Issawi, 2020, p. 633) by creating opportunities for agonistic debates necessary for future developments towards democratisation.

From early on, Mada Masr collaborated with nonjournalistic individuals as well as organisations and other media outlets to broaden its reporting and outreach. Its acquaintance with the like-minded editors of the Jordanian 7iber started in 2011, but Mada Masr has been a part of the Arab bloggers and techies' community from even further back (Attalah, 2019, p. 13). Since 2016, Mada Masr has been part of the network Independent Media of the Arab World (Orient XXI, 2018). The most recent examples of producing high-quality, relevant content in a collaborative effort are a visual reconstruction of the 2020 Beirut port explosion with Forensic Architecture (2020) and the 2021 webinars about the Covid-19 pandemic with the Arab Reform Initiative (2021).

Having decided against implementing a paywall and being unable to attract large amounts of advertisement, Mada Masr has set up a membership programme to secure some of its funding. It offers four tiers, with the cheapest aimed at Egyptian readers and the most expensive at well-funded international organisations and wealthy supporters. As of 2017, about one-third of the paying subscribers to its daily press review Morning Digest were located abroad, while the majority of readers was based in Egypt (Tesdell, 2017). In addition, the team offers services such as translation or editing as part of their business model.

However, about 80 percent of its funding still is provided through grants by foundations and other philanthropic organisations (Chaudhary, 2019; "How necessity drives," 2019; Tesdell, 2017), such as the Prince Claus Fund or International Media Support. It does share this fate with many other non-profit media outlets around the world, such as the highly successful US-American Texas Tribune or ProPublica, who similarly have not yet found a sustainable business model that might compensate for the collapse of the advertising-based revenue models.

\section{Conclusion}

Tracing the development of Mada Masr against the background of different phases of transition in the 
Egyptian media scene provides insight into the mechanics of transformation. In the Egyptian case, the transformation process towards a freer media was halted by a multitude of factors, among them increased political pressure, ownership structures, and inherited newsroom practices.

The outlet came to life during an opening up of the Egyptian media scene, marked by the growing influence of newly founded and privately-owned media outlets that pushed the lines of what could be reported in tandem with a lively blogosphere and pan-Arab television channels which highlighted corruption and abuse by state authorities. During this onset phase to further political transformation, the newsroom of Al Masry Al Youm's English Edition certainly played a role as a dissenting voice and an agent of change.

With the massive uprisings of early 2011, triggered by the ousting of long-time Tunisian president Zine el-Abidine Ben Ali, the country underwent a shift from soft authoritarianism into a transition phase. Similar to phases of political transition in other countries, the development of the media in Egypt was not only an indication of that shift, but that the media had itself become an actor (Jones, 2002, p. 452). New media outlets and news formats flourished, journalists pushed the red lines even further, and discussions about the future of Egyptian media ensued (Jones, 2002, pp. 455-459). In the case of Egypt, counter-attacks by former regime members and a lack of professionalism in journalism (Jones, 2002, p. 456)-among a multitude of other factors-led to vicious media wars over the progress of the country's transformation. Consequently, after the summer of 2013, the country relapsed back to an authoritarian regime that cracked down hard on any dissent and increased its tools for controlling the media further to the point that made "the margin of manoeuvre for genuine change almost impossible" (El Issawi, 2020, p. 642).

The staff of Al Masry Al Youm's English edition had been involved in the run-up to the events of January 2011 by maintaining personal relationships with political activists striving for democratisation and reporting on the growing dissent, protests, demonstrations, and transgressions by state authorities. During the transition phase, the newsroom made use of the larger margins of freedom, reporting on the struggle for political power, tapping into additional sources of information and tackling issues that had previously been off-limits. Simultaneously, the outlet reached a wider impact by preparing to publish a weekly printed edition while adhering to the professional standards that had guided its professional practice since its foundation. Their understanding of journalistic professionalism stemmed from the personal experiences of the inherited practices and structures of other newsrooms, thus combining values of Western journalism with the necessities of manoeuvring in an authoritarian environment.

At the peak of the political confrontation in spring 2013, the leadership of the Arabic mother paper decided to shut the newsroom down. Its comeback in summer 2013 as the news outlet Mada Masr was timed to cover the massive protests of both political camps that eventually led to the ousting of then-president Morsi and the seizure of power by members of the former political forces. Although the claim to produce truthful, progressive journalism did not change; the staff had to adapt its practices and newsroom structure according to the changing economic and political circumstances. This not only included taking over responsibilities other than journalistic work and negotiating its working relationships anew. It also meant a sharpened awareness of its role as one of the few remaining dissident voices, of journalism as an act of political contention, and of themselves as adversarial watchdogs. Finding themselves a target of increasing political oppression required the outlet's staff to not only acquire and implement a deeper knowledge of digital security but also to rigorously implement professional norms as well as self-censorship to protect the outlet. In its pursuit of truthful journalism, the small news outlet widened its outreach and scope of production and made itself part of different communities that provided a support system as well as a purpose. However, despite being well-connected agents of change who stubbornly and creatively defy the limitations of their surroundings, its status is fragile.

Nevertheless, its strategies for survival make Mada Masr a role model for media outlets that navigate in authoritarian environments as well as for those who struggle with the massive transformations of the profession worldwide.

\section{Acknowledgments}

Due to the political repression in Egypt and in order to minimise the risk of bodily or other harm, the names of the interviewees are not disclosed. Fieldwork was conducted in Cairo between March 2011 and December 2013.

\section{Conflict of Interests}

The author declares no conflict of interest.

\section{Disclaimer}

The Arab-German Young Academy of Sciences and Humanities (AGYA) is supporting the thematic issue "Ten Years after the Arab Uprisings: Beyond Media and Liberation," edited by AGYA alumna Hanan Badr (Gulf University of Science and Technology, Kuwait) and AGYA member Lena-Maria Möller (Max Planck Institute for Comparative and International Private Law, Germany). AGYA is funded by the German Federal Ministry of Education and Research (BMBF). The authors remain solely responsible for the content and recommendations provided in this publication, which do not reflect the positions of AGYA or any of its funding partners. 


\section{References}

42 words on page 3: How Morsi died in Egyptian newspapers. (2019, June 18). Mada Masr. https://www. madamasr.com/en/2019/06/18/feature/politics/42words-on-page-3-how-morsi-died-in-egyptiannewspapers

Abdallah, R. (2014). Egypt's media in the midst of revolution. Carnegie Endowment for International Peace. http://carnegieendowment.org/files/egypt_ media_revolution.pdf

Abdelhadi, M. (2015, August 7). Independent journalism finds its voice in Egypt. Nieman Reports. https:// nieman.harvard.edu/articles/independentjournalism-finds-its-voice-in-egypt

Afifi, H. (2014, July 3). Reporting Egypt: From passion to purpose. Jadaliyya. https://www.jadaliyya.com/ Details/30902c

And we're back. (2013, June 29). Mada Masr. https:// madamasr.com/en/2013/06/29/feature/politics/ and-were-back

Arab Reform Initiative. (2021, February 23). Social protection in (post)Covid-19 MENA. https://www.arabreform.net/project/social-protection-in-postcovid19-mena

Association for Freedom of Thought and Expression. (n.d.). Blocked website's list. https://afteegypt.org/ en/blocked-websites-list\#

Attalah, L. (2017, July 2). From boredom to labor and labor to boredom. Mada Masr. https://madamasr. com/en/2017/07/02/opinion/u/from-boredom-tolabor-and-labor-to-boredom

Attalah, L. (2019). Innovative Arab media and the new outlines of citizenship. A collaborative vision builds stronger journalism across the region. The Century Foundation. https://tcf.org/content/report/ innovative-arab-media-new-outlines-citizenship/ ?session=1

Attalah, L., \& Mossalam, A. (2014, January 4). On the love of life and Alaa's detention. Mada Masr. http://www.madamasr.com/en/2014/01/04/ opinion/u/on-the-love-of-life-and-alaas-detention

Badr, H. (2017). Framing von Terrorismus im Nahostkonflikt. Eine Analyse deutscher und ägyptischer Printmedien [Terrorism in the Middle East conflict. An analysis of German and Egyptian print media]. Springer. https://doi.org/10.1007/978-3-658-17393-7

Badr, H. (2020). From disruptive power to trapped endurance: Egypt's journalistic agency after the Tahrir Revolution. In E. Tandoc, J. Jenkins, R. Thomas, \& O. Westlund (Eds.), Critical incidents in journalism: Pivotal moments reshaping journalism around the world (pp. 216-229). Routledge. https://doi.org/ $10.4324 / 9781003019688$

Badran, Y., \& Smets, K. (2018). Heterogeneity in alternative media spheres: Oppositional media and the framing of sectarianism in the Syrian conflict. International Journal of Communication, 12, 4229-4247. https://ijoc.org/index.php/ijoc/article/view/8472

Becoming "legal": On Mada Masr's decision to apply for a licence under the new media law. (2018, November 25) Mada Masr. https://madamasr.com/ en/2018/11/25/opinion/u/becoming-legal-onmada-masrs-decision-to-apply-for-a-license-underthe-new-media-law

Chammah, M. (2011, December 13). The springborg affair: A censorship debacle reflects Egypt's future. Huffington Post. http://www.huffingtonpost.com/ maurice-chammah/egypt-media-censorshipspingborg_b_1146133.html

Chang, L. T. (2015, January 27). The news website that's keeping press freedom alive in Egypt. The Guardian. http://www.theguardian.com/news/2015/jan/27/sp-online-newspaper-keeping-press-freedom-aliveegypt

Chaudhary, S. (2019, November 26). Egypt's investigative news organisation raided, media clampdown continues. The Citizen. https://www.thecitizen.in/ index.php/en/NewsDetail/index/6/17909/EgyptsInvestigative-News-Organisation-Raided-MediaClampdown-Continues

Dean, L. C. (2017). All truth is worth publishing. Mada Masr and the fight for free speech in Egypt. The Century Foundation. https://tcf.org/content/report/ truth-worth-publishing/?agreed=1\&agreed=1

Downing, J. (1996). Internationalizing media theory: Transition, power, culture. Reflections on media in Russia, Poland, and Hungary 1980-95. SAGE.

El Issawi, F. (2020). Egyptian journalists and the struggle for change following the 2011 uprising: The ambiguous journalistic agency between change and conformity. International Communication Gazette, 82(7), 628-645. https://doi.org/10.1177/ 1748048519897516

El Issawi, F., \& Cammaerts, B. (2016). Shifting journalistic roles in democratic transitions: Lessons from Egypt. Journalism, 17(5), 549-566. https://doi.org/ 10.1177\%2F1464884915576732

Elmasry, M. H. (2009). Producing the news in Egypt. A press study of Cairo newspapers [Doctoral thesis, The University of lowa]. ProQuest. http:// search.proquest.com/docview/304904228? accountid $=14531$

Fahmy, N. (2019). How the Egyptian state codifies media censorship. The Tahrir Institute for Middle East Policy. https://timep.org/commentary/analysis/ how-the-egyptian-state-codifies-media-censorship

Fandy, M. (2000). Information technology, trust and social change in the Arab world. Middle East Journal, 54(3), 378-394. https://www.jstor.org/stable/ 4329507

Forensic Architecture. (2020). The Beirut port explosion. https://forensic-architecture.org/investigation/ beirut-port-explosion

Hafez, K. (2014). Arab and Western media systems typologies. In L. Hudson, A. Iskandar, \& M. Kirk 
(Eds.), Media evolution on the eve of the Arab Spring (pp. 235-50). Palgrave Macmillan. https://doi.org/ 10.1057/9781137403155_15

Hagmann, J. (2013, September 30). The media are PR machines of the military: Interview with Lina Attalah. Quantara. https://en.qantara.de/node/17032 5

Hallin, D. C., \& Mancini, P. (2004). Comparing media systems. Three models of media and politics. Cambridge University Press.

Hamama, M. (2017, May 26). 24 hours later: What we know about the blocking of Mada Masr's website. Mada Masr. https://www.madamasr.com/en/2017/ 05/26/feature/politics/24-hours-later-what-weknow-about-the-blocking-of-mada-masrs-website

Hamoud, M. (2019). Hegemony and the interest of Egypt's business elite in post-Mubarak press. New Middle Eastern Studies, 9(1), 115-132. https:// www108.lamp.le.ac.uk/ojs1/index.php/nmes/ article/download/3131/2819

Harb, Z. (2018). After the Arab revolts: Social media and the journalist in Egypt. In S. Price (Ed.), Journalism, power, and investigation global and activist perspectives (pp. 215-225). Routledge. https://openaccess. city.ac.uk/id/eprint/21305

Harb, Z. (2019). Journalism cultures in Egypt and Lebanon: Role perception, professional practices, and ethical considerations. In F. Resende \& M. Iqani (Eds.), Global South: Narrative territorialities, crosscultural flow (pp. 125-146). Routledge.

Hill, E. (2013, October 7). In Egypt, an unhappy medium. Al Jazeera English. http://america.aljazeera.com/ articles/2013/10/7/in-egypt-an-unhappymedium. html

How necessity drives media innovation in the Middle East, North Africa. (2019, January 6). Arab Reporters for Investigative Journalism. https://en.arij. net/news/how-necessity-drives-media-innovationin-middle-east-north-africa

Hussein, J. (2019, July 28). How Mada Masr is surviving Egypt's authoritarianism. The Dawn. https://www. dawn.com/news/1494407

International Press Institute. (2019, April 16). Egyptian news site Mada Masr named 2019 Free Media Pioneer. https://ipi.media/egyptian-news-site-madamasr-named-2019-free-media-pioneer

Jones, A. (2002). The press in transition. A comparative study of Nicaragua, South Africa, Jordan, and Russia. Deutsches Übersee-Institut.

Khoury, D. (2012). Social media and the revolutions. How the internet revived the Arab public sphere and digitalized activism. Perspectives, 2(12), 80-85.

Mada Masr. (2021, March 3). Letter from our editor.

Media Ownership Monitor Egypt. (2018). Mada Masr. https://egypt.mom-rsf.org/en/media/detail/outlet/ mada-masr/

Neither victory nor defeat: Court refers Mada Masr blocking case for technical review. (2018, September 20). Mada Masr. https://madamasr.com/ en/2018/09/30/news/u/neither-victory-nordefeat-court-refers-mada-masr-blocking-casefor-technical-review

Orient XXI. (2018). Médias indépendants sur le monde arabe [Independent media in the Arab world]. https://orientxxi.info/informations/mediasindependants-sur-le-monde-arabe,2656

Ressa, M. (2020, September 22). The 100 most influential people of 2020: Lina Attalah. Time. https://time.com/collection/100-most-influentialpeople-2020/5888226/lina-attalah

Richter, C. (2011). Medienstrategien ägyptischer Islamisten im Kontext von Demokratisierung [Media strategies of Egyptian Islamists in the context of democratization]. Frank und Timme.

Richter, C. (2015). Ägypten: Paradox von Vielfalt und Gleichschaltung [Egypt: Paradox of diversity and conformity]. In C. Richter \& A. El Difraoui (Eds.), Arabische Medien [Arab Media] (pp. 131-142). UVK.

Rinke, E. M., \& Röder, M. (2011). Media ecologies, communication culture, and temporal-spatial unfolding: Three components in a communication model of the Egyptian regime change. International Journal of Communication, 5, 1273-1285.

Roudakova, N. (2011). Comparing processes. Media, "transitions," and historical change. In D. Hallin \& P. Mancini (Eds.), Comparing media systems beyond the Western world (pp. 246-277). Cambridge University Press. https://doi.org/10.1017/CBO9781139005098. 014

Sakr, N. (2013). Transformations in Egyptian journalism. I.B. Tauris.

Sakr, N. (2016). Survival or sustainability? Contributions of innovatively managed news ventures to the future of Egyptian journalism. Journal of Media Business Studies, 13(1), 45-59. https://doi.org/10.1080/ 16522354.2015.1125608

Sandels, A. (2009, August 18). Big plans appear to be in the pipeline in Cairo.... Menassat. www.menassat. com/?q=en/news-articles/7132-al-masry-al-youmenglish-new-kid-block-egyptian-media

Schröder, C. (2015). Interview mit Lina Attalah: Hau ab, wenn es brenzlig wird [Interview with Lina Attalah: Run away when things get tough]. Das Medienmagazin Journalist, 65(3), 28-30.

Shoemaker, P. J., \& Reese, S. D. (2014). Mediating the message in the 21st century: A media sociology perspective. Routledge.

Shoemaker, P. J., \& Vos, T. P. (2009). Gatekeeping theory. Taylor \& Francis.

Tesdell, R. (2017, June 7). Mada Masr, Egypt's poster child for digital news, begins its foray into a readerfunded model. Niemanlab. https://www.niemanlab. org/2017/06/mada-masr-egypts-poster-child-fordigital-news-begins-its-foray-into-a-reader-fundedmodel

Time. (n.d.). Next generation leaders 2017. https://time. com/collection/next-generation-leaders/\#2017 
UNESCO. (2013). Assessment of media development in Egypt based on UNESCO's media development indicators. http://unesdoc.unesco.org/images/0022/ 002207/220742e.pdf

Vladisavljevic, N., \& Voltmer, K. (2017). Media framing of democratisation conflicts in Egypt, Kenya, Serbia, and South Africa: A content analysis (Working Paper). MeCoDEM. http://www.mecodem.eu/wpcontent/uploads/2017/02/Vladisavljevi\%C4\%87-

Voltmer-2017_Media-framing-of-democratisationconflicts-in-Egypt-Kenya-Serbia-and-South-Africa_a-content-analysis.pdf

Voltmer, K. (2013). The media in transitional democracies. Polity Press.
Wackenhut, A. F. (2019). Revisiting the Egyptian uprising of 2011: Exploring the role of relational networks within the Cairo-based political opposition. Social Problems, 67(2), 342-357. https://doi.org/10.1093/ socpro/spz014

Weaver, D. H., Willnat, L., \& Wilhoit, G. C. (2018). The American journalist in the digital age: Another look at US news people. Journalism \& Mass Communication Quarterly, 96(1), 101-130. https://doi.org/10.1177\% 2F1077699018778242

Wrestling in Egypt. (2018, October 8). Synaps. https://www.synaps.network/post/egyptjournalism-reporting-mada-masr

\section{About the Author}

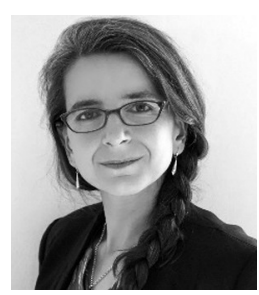

Nadia Leihs currently is a freelance researcher and journalist. From October 2014 to November 2020, she worked at the Erich Brost Institute, Technische Universität Dortmund, and was involved in the Erasmus+ funded project NEWSREEL and the project Ombudsmen in Tunisia. She is a PhD candidate at the University of Erfurt and the Freie Universität Berlin. Her research interests include the influence of institutional structures on journalistic content and the media's role in social and political transformation processes. 